\title{
The Effect of Geo political risk on China's OFDI: A Research Based on Countries along the line of The Belt and Road Initiative
}

\author{
Ying Liu \\ School of insurance, \\ Central University of Finance and Economics, \\ Beijing, China
}

\begin{abstract}
China's overall investment in ASEAN, Western Asia and Central Asia has been relatively large since the "one belt and one way" initiative, while the countries in Central and Eastern Europe and South Asia are less. Geopolitical economic risk is an important factor. In this paper, we use the inventory data of China's direct investment in the "one belt and one road" country for 2005-2013 years, the geopolitical risk index calculated by each sub index score of geopolitical risk released in ICRG, and the data of the system's scoring system of the world bank's development index database issued annually. Component analysis and fixed effect stepwise regression model are used to explore the impact of geopolitical risk on China's OFDI along the "one belt and one road" area. The results show that geopolitical risk has a direct negative effect on outward FDI, that is, China tends to invest in countries (regions) with higher geopolitical risk, which may be caused by foreign policy and resource endowment; further analysis found that factors of exchange rate index, per capita GDP, resource endowment, infrastructure, economic and legal freedom positively promote OFDI, while R\&D expenditure has a negative impact on OFDI, which may be due to R\&D delay. Therefore, we need to stabilize the political and economic relations among the countries along the belt and road, increase the transparency of investment information of the host country, and strengthen the enterprise's self-awareness.
\end{abstract}

Keywords: Geo Political Risk; The Belt and Road ;OFDI; Institutional Environment.

\section{INTRODUCTION}

According to the data of China's foreign direct investment statistics bulletin, by the end of 2017, China's foreign direct investment stock had reached 1809.04 billion US dollars, accounting for $5.9 \%$ of the global foreign direct investment outflow stock, which was distributed in 189 countries and regions around the world. The stock size increased by 451.65 billion US dollars compared with the end of last year, exceeding the level of foreign investment absorption in the same period, ranking second in the world, and ranking second in the global stock The ranking jumped to the second place, four places higher than the previous year. In 2017, although China's foreign direct investment showed negative growth for the first time, it still ranked the third place in the world with us $\$ 158.3$ billion, exceeding the level of foreign investment absorption in the same period. With the deepening of international exchanges between China and the countries along the "one belt and one road", the direct investment flows of China along the "one belt and one road" area showed a trend of rapid growth at the end of 2014 (Table 2). At the end of this year, the stock of investment was US $\$ 92$ billion 460 million, which accounted for $10.5 \%$ of China's foreign direct investment stock in that year. In 2018, Chinese enterprises invested 15 billion 640 million dollars in non-financial direct investment in 56 countries along the belt Road, an increase of $8.9 \%$ over the previous year, accounting for $13 \%$ of the total period of the same period, and mainly invested in Singapore, Laos, Vietnam, Indonesia, Pakistan, Malaysia, Russia, Kampuchea, Thailand and the United Arab Emirates. 
Figure 1 China's foreign direct investment stock in 2003-2017

\section{China's foreign direct investment stock from 2003 to 2017 Unit: USD 10000}

$200,000,000$

$150,000,000$

$100,000,000$

$50,000,000$

200320042005200620072008200920102011201220132014201520162017

Data source: 2017 China Foreign Direct Investment Statistics Bulletin of the Ministry of Commerce

Table 1 geographical distribution of countries along the "one belt and one road" area

\begin{tabular}{c|l}
\hline \multicolumn{1}{c|}{ Regions } & \multicolumn{1}{c}{ Major countries } \\
\hline East Asia (1 country) & \multicolumn{1}{c}{ Mongolia; } \\
\hline Central Asia (5 countries) & $\begin{array}{l}\text { Kazakhstan, Uzbekistan, Turkmenistan, Tajikistan and } \\
\text { Kyrgyzstan; }\end{array}$ \\
\hline CIS (7 countries) & $\begin{array}{l}\text { Russia, Ukraine, Belarus, Georgia, Azerbaijan, Armenia } \\
\text { and Moldova; }\end{array}$ \\
\hline South Asia (8 countries) & $\begin{array}{l}\text { India, Pakistan, Bangladesh, Afghanistan, Sri Lanka, } \\
\text { Maldives, Nepal and Bhutan; }\end{array}$ \\
\hline Central and Eastern Europe (16 countries) & $\begin{array}{l}\text { Singapore, Malaysia, Indonesia, Myanmar, Thailand, } \\
\text { Laos, Cambodia, Vietnam, Brunei and the Philippines; } \\
\text { Herzegovina, Montenegro, Serbia, Albania, Romania, } \\
\text { Bulgaria and Macedonia; }\end{array}$ \\
\hline Western Asia (18 countries) & $\begin{array}{l}\text { Iran, Iraq, Turkey, Syria, Jordan, Lebanon, Israel, } \\
\text { Palestine, Saudi Arabia, Yemen, Oman, UAE, Qatar, } \\
\text { Kuwait, Bahrain, Greece, Cyprus and Sinai Peninsula of } \\
\text { Egypt; }\end{array}$ \\
\hline
\end{tabular}


Table 2 China's location of direct investment flows along the "one belt and one road" area: US $\$ 100$ million

\begin{tabular}{c|c|c|c|c|c|c|c}
\hline & East Asia & ASEAN & $\begin{array}{c}\text { Western } \\
\text { Asia }\end{array}$ & South Asia & Central Asia & CIS & $\begin{array}{c}\text { Central and } \\
\text { Eastern } \\
\text { Europe }\end{array}$ \\
\hline 2005 & 0.5 & 1.6 & 1.2 & 0.2 & 1.1 & 2.1 & 0.1 \\
\hline 2006 & 0.8 & 3.4 & 2.6 & -0.5 & 0.8 & 4.7 & 0.2 \\
\hline 2007 & 2 & 9.7 & 2.5 & 9.4 & 3.8 & 4.9 & 0.3 \\
\hline 2008 & 2.4 & 24.8 & 2.1 & 4.9 & 6.6 & 4.1 & 0.4 \\
\hline 2009 & 2.8 & 27 & 7.3 & 0.8 & 3.5 & 3.6 & 0.4 \\
\hline 2010 & 1.9 & 44 & 11 & 4.2 & 5.8 & 6.3 & 4.2 \\
\hline 2011 & 4.5 & 59.1 & 14.3 & 9.1 & 4.5 & 7.4 & 1.3 \\
\hline 2012 & 9 & 61 & 14.5 & 4.4 & 33.8 & 9 & 1.5 \\
\hline 2013 & 3.9 & 72.7 & 22.3 & 4.6 & 11 & 11.6 & 1 \\
\hline 2014 & 8.5 & 85 & 25 & 5.2 & 30 & 15.2 & 3 \\
\hline
\end{tabular}

As can be seen from table 2, China's overall investment in ASEAN, West Asia and Central Asia accounts for a large proportion, while that in central and Eastern Europe and South Asia is relatively small, among which geopolitical and economic risks are an important factor. China's foreign direct investment is located in six continents, and the distribution is relatively concentrated and has certain rules. According to the traditional theory of international capital flow, capital should mainly flow from developed countries to developing countries. However, as a developing country, China is attracting a lot of foreign investment, but also has a largescale capital export phenomenon, and a lot of capital flows to developed countries. As the world's second largest capital exporter, there are many factors for the flow of these capital overseas, some of which are to explore the international market, make use of rich foreign resources, so as to improve the international competitiveness of enterprises and obtain high profits, some of which are to pursue the efficient operation environment of foreign low-level political risk environment and system, and to improve profits from the aspect of reducing transaction costs Moisten. The political situation among countries directly affects economic activities such as trade and investment. The geopolitical risk of the countries along the "one belt and one road" includes the political risk of the state in the region and the risk of big country strategic conflict, which is characterized by complexity and variety. The position and particularity of the countries along the belt in the international political situation is closely related to the economic strategic deployment of big powers. Specifically, China's "one belt and one road" initiative has attracted us criticism. The new multilateral mechanism formed by its effective implementation has strongly counterbalanced the impact of Sino US trade war. In the critical period of international political turmoil and the rapid development of China's economy, it is very important to study the geopolitical risks of the countries along the belt and road to the current and future economic and trade development in China.

So what is the relationship between China's capital export and host country's geopolitical risk? Especially in the context of Sino US trade friction, it is of great theoretical and practical significance to study the investment environment of the host country of "one belt and one road" and what factors seriously affect the decision of China's foreign direct investment..

\section{MODEL}

Referring to buckly (2007), the data used in this paper is panel data including time characteristics and section characteristics. The measurement model is established as follows: 
$\mathrm{z} \_O F D I_{\text {it }} \quad=\tau_{0} \quad+\tau_{1} \mathrm{z}_{-}$political $_{i t} \quad+\tau_{2} \mathrm{z}_{-}$research $_{i t} \quad+\tau_{3} \mathrm{z}_{-} P G D P_{i t} \quad+\tau_{4} \mathrm{z}_{-} H U_{i t}$

$+\tau_{5} \mathrm{Z} \_$INF_Rail ${ }_{\mathrm{it}}+\tau_{6} \mathrm{z} \_\mathrm{Exch}_{\mathrm{it}}+\tau_{7} \mathrm{z}$ Fuel $_{\mathrm{it}}+\tau_{8} \mathrm{z}$ freedom $_{i t}+Z_{i}^{\prime} \delta+\mu_{i}+\varepsilon_{i t}$

$\mathrm{Z}$ Indicates that the variables have been standardized, and the meaning of each variable is shown in the table. Where I represents the country and T represents the year. The disturbance term consists of two parts: individual invariant disturbance and individual variable disturbance. The Chi sq statistical value of Hausman test of the model in this paper is 41.89, which is significant at 1\% significance level, so the original hypothesis cannot be accepted. The original hypothesis is to choose random effect, so this paper uses fixed effect model to analyze. At the same time, in regression analysis, robust standard error is used to avoid the influence of heteroscedasticity on the accuracy of regression results.

Table 3 List of variable meanings

\begin{tabular}{|c|c|c|c|}
\hline $\begin{array}{l}\text { Variable } \\
\text { type }\end{array}$ & $\begin{array}{l}\text { Variable } \\
\text { name }\end{array}$ & Variable meaning & Measure index \\
\hline $\begin{array}{l}\text { Explained } \\
\text { variable }\end{array}$ & OFDI & Foreign direct investment & $\begin{array}{l}\text { China's stock of non-financial } \\
\text { foreign direct investment }\end{array}$ \\
\hline $\begin{array}{l}\text { Explanatory } \\
\text { variable }\end{array}$ & POLITICAL & $\begin{array}{l}\text { Geopolitical risk index: indicates the } \\
\text { risk situation of a country's political } \\
\text { environment. The higher the score, the } \\
\text { better }\end{array}$ & $\begin{array}{l}\text { Total scores of geopolitical risk } \\
\text { assessment institutions }\end{array}$ \\
\hline \multirow{7}{*}{$\begin{array}{l}\text { Control } \\
\text { variable }\end{array}$} & Research & $\begin{array}{l}\text { R \& D Expenditure: a measure of a } \\
\text { country's R \& D investment }\end{array}$ & $\begin{array}{l}\text { Sum of R \& D expenditure of } \\
\text { current account and capital } \\
\text { account }\end{array}$ \\
\hline & PGDP & $\begin{array}{l}\text { GDP per capita: a measure of the } \\
\text { country's overall economic situation }\end{array}$ & GDP per capita (current price USD) \\
\hline & HU & $\begin{array}{l}\text { Human capital: measuring workers' } \\
\text { access to knowledge }\end{array}$ & $\begin{array}{l}\text { Ratio of education expenditure to } \\
\text { GDP }\end{array}$ \\
\hline & INF_Rail & $\begin{array}{l}\text { Railway Infrastructure: measuring the } \\
\text { perfection of national infrastructure }\end{array}$ & $\begin{array}{l}\text { Total kilometers of Railways in } \\
\text { different countries (regions) }\end{array}$ \\
\hline & Exch & Real exchange rate index & 2010 as the base period \\
\hline & Fuel & Resource endowment & $\begin{array}{l}\text { Fuel exports of host countries as a } \\
\text { percentage of commodity exports }\end{array}$ \\
\hline & Freedom & Institutional freedom of the country & Economic and legal freedom \\
\hline
\end{tabular}

On the basis of a comprehensive understanding of the connotation of geopolitical risk and previous studies, this paper uses a series of indicators of geopolitical risk published by ICRG to build geopolitical risk index, and constructs geopolitical risk institutional environment index from two aspects, each part of which reflects the different aspects of geopolitical risk related systems.

\section{DATA}

According to the availability and applicability of the data, the data of the indicators selected by the author are respectively from the 2014 China foreign direct investment statistical bulletin jointly prepared by the Ministry of Commerce, the Bureau of statistics and the State Administration of foreign exchange; the geopolitical risk index as an explanatory variable, the data are from the geopolitical risk score data published by the political risk group; the data are the control change The volume of data comes from the world bank development indicators 
database, as well as the calculated system freedom index, and the data comes from the American Heritage Foundation.

This paper studies the influence of geopolitical risk on the location choice of OFDI in China. Therefore, the explanatory variables of this paper can be chosen as OFDI traffic and stock data. The reasons for choosing the stock are: (1) the flow study period is relatively short, and during the period of this study, the fluctuation of OFDI traffic in China is huge, which is not conducive to interpretation; OFDI flow data. Influenced by random factors, it is easy to have data fluctuations and affect the stability of regression results; (3) the negative value of flow data makes it impossible to use log model for measurement calculation. "One belt and one road" involves 65 countries (regions). Due to the lack of data in some countries and the 30 countries selected from 2005 to 2013, non-financial outward direct investment accounts for $82.78 \%$ of the 65 countries (regions), and non financial foreign direct investment accounts for $83.51 \%$ of 65 countries, so the selected countries are representative.

This paper studies the influence of geopolitical risk on foreign direct investment, so chooses geopolitical risk index as the explanatory variable, and the data comes from the geopolitical risk score data released by political risk group. Referring to buckly (2007), this paper selects geopolitical risks as explanatory variables and several factors that may significantly affect OFDI as control variables. Specifically as follows: research refers to the total innovative work of a country, that is, the total expenditure of the national sector and the private sector, including the current account and the capital account; per capital GDP (PGDP) refers to the amount of per capita annual average GDP of a country (current dollar); human resources (HU), which refers to The standard is measured by the ratio of education expenditure to GDP; infrastructure, the more perfect a country's infrastructure is, the more cost-effective it will be, thus contributing to the smooth progress of foreign direct investment; exchange rate, the real effective exchange rate, is the nominal effective exchange rate (the measurement method of the ratio of the value of local currency to the weighted average value of some foreign currencies) divided by the deflated price Index or cost index; fuel, which is calculated by the ratio of national fuel exports to commodity exports; freedom, which is calculated by the previous principal component analysis method, indicates a country's social institutional environment. The higher the score is, the more perfect the institutional environment is, the more favorable it is to attract foreign investment.

\section{The construction of index of system freedom}

\section{EMPIRICAL ANALYSIS}

Institution is a multi-dimensional concept, which has different weights and directions. It is a vector concept, which needs to start from the perspective of econometrics. On the basis of a comprehensive understanding of the factors affecting foreign direct investment and previous studies, this paper constructs system freedom indicators from two aspects of economy and law, reflecting different aspects of the system respectively. The perfection of economy and legal system directly affects the attraction of capital. The degree of economic freedom evaluates the openness of a country's foreign economic trade.

Based on the previous research and analysis, combined with the research objectives of this paper, the following six indicators of economic freedom are used to measure. They are: commercial freedom, trade freedom, fiscal freedom, monetary freedom, financial freedom and labor freedom. At the legal level, the property right system is chosen. To some extent, the selection of the above indicators of freedom will affect the transaction cost of foreign direct investment. 
In this set of indexes, there are two aspect indexes and seven sub indexes. These indicators have authoritative data in the world and exist in the form of scoring (0-100 points). These data are processed to form a single index corresponding to the index, and then several indexes belonging to the same aspect are used to synthesize the aspect index according to a certain weight, and finally two aspects are used to synthesize the total index according to a certain weight.

The formation of each single index provides the basis for the synthesis of the total index of the system, and the key to the synthesis of the total index is to choose the weight. In order to avoid the interference of multicollinearity, this paper uses principal components analysis to determine the weight of each single index in the total index, so as to synthesize the total index. For example, first of all, principal component analysis was conducted on the sub indicators of national systems in 2013. Through the results of stata13.0, the variance contribution rate and cumulative contribution rate of each component in Table 5 were obtained. It can be known that the first two characteristic roots are greater than 1, and the variance contribution rate of the first two principal components is $68.06 \%$ (cumulative\%). KMO test data (Table 5).

Table 4 variance contribution rate and cumulative contribution rate of components

\begin{tabular}{c|c|c|c|c}
\hline component & $\begin{array}{c}\text { characteristic } \\
\text { value }\end{array}$ & variance & $\begin{array}{c}\text { Variance } \\
\text { contribution } \\
\text { rate }\end{array}$ & $\begin{array}{c}\text { Cumulative } \\
\text { contribution } \\
\text { rate }\end{array}$ \\
\hline component 1 & 3.47105 & 2.1777 & 0.4959 & 0.4959 \\
\hline component 2 & 1.29335 & .518415 & 0.1848 & 0.6806 \\
\hline component 3 & .774937 & .191649 & 0.1107 & 0.7913 \\
\hline component 4 & .583288 & .124958 & 0.0833 & 0.8747 \\
\hline component 5 & .458331 & .165847 & 0.0655 & 0.9401 \\
\hline component 6 & .292484 & .165925 & 0.0418 & 0.9819 \\
\hline component 7 & .126559 &. & 0.0181 & 1.0000 \\
\hline
\end{tabular}

Table 5 KMO test

\begin{tabular}{c|c}
\hline Variables & KMO \\
\hline Freedom of property rights & 0.8656 \\
\hline Monetary freedom & 0.7710 \\
\hline Freedom of trade & 0.7824 \\
\hline Financial freedom & 0.6674 \\
\hline Freedom of labor & 0.7418 \\
\hline Fiscal freedom & 0.3620 \\
\hline Freedom of business & 0.7848 \\
\hline Total & 0.7354 \\
\hline
\end{tabular}

From table 5, we can see that the kmo test value is 0.7354 . In addition to financial freedom, all variables basically meet the requirements. Therefore, delete the financial freedom variables and do kmo test and principal component analysis again. The results show that the eigenvalues of the first two principal components are greater than one, and the cumulative contribution 
value is improved to $74.19 \%$, so the first two principal components are enough to describe. The corresponding kmo test results show that the adjusted test values of each variable are improved, which is more suitable for principal component analysis.

Then, by rotating the load matrix, the corresponding eigenvector can be obtained. Take 2013 as an example, and other years as follows:

The total score of principal components in 2013 is:

$$
\mathrm{P}=0.5704^{*} \mathrm{~F} 1+0.1715^{*} \mathrm{~F} 2
$$

Take the first two eigenvalues, and the corresponding eigenvectors are shown in the table below:

Table 6 Corresponding eigenvectors

\begin{tabular}{c|c|c}
\hline & F1 & F2 \\
\hline Freedom of property rights & 0.4712 & 0.1511 \\
\hline Monetary freedom & 0.4307 & 0.3886 \\
\hline Freedom of trade & 0.4223 & 0.0487 \\
\hline Financial freedom & 0.4909 & 0.2592 \\
\hline Freedom of labor & 0.3242 & 0.4833 \\
\hline Freedom of business & 0.2608 & 0.7232 \\
\hline
\end{tabular}

After getting the principal component, we can give weight to each sub index in the system index and synthesize the system index.

The corresponding composition calculation method is as follows:

$\mathrm{F} 1=0.4712 *$ freedom of property right $+0.4307 *$ freedom of currency $+0.4223 *$ freedom of trade $+0.4909 *$ freedom of Finance $+0.3242 *$ freedom of labor $+0.2608 *$ freedom of business

$\mathrm{F} 2=-0.1511 *$ freedom of property rights $-0.3886 *$ freedom of currency $+0.0487 *$ freedom of trade $-0.2592 *$ freedom of Finance $+0.4833 *$ freedom of labor $+0.7232 *$ freedom of business Total score: $\quad$ freedom $=0.5704 * \mathrm{~F} 1+0.1715 * \mathrm{~F} 2$

According to this formula, the final score of institutional freedom of each country in 2013 can be calculated.

\section{RESULTS}

The analysis and test of the standardized data are as follows. First, the correlation of each variable was analyzed, then the multicollinearity diagnosis was carried out. Using stata13.0, the variance expansion factor (VIF) value of each variable was obtained. The statistical results showed that the variance expansion factor of each variable was less than 10 , indicating that there was no multicollinearity in each variable. In order to investigate the robustness of geopolitical risk, we gradually add a series of control variables into the regression equation. The regression results are shown in Table 7: 
Table 7 Empirical results of OFDI stepwise regression (FE) for each variable

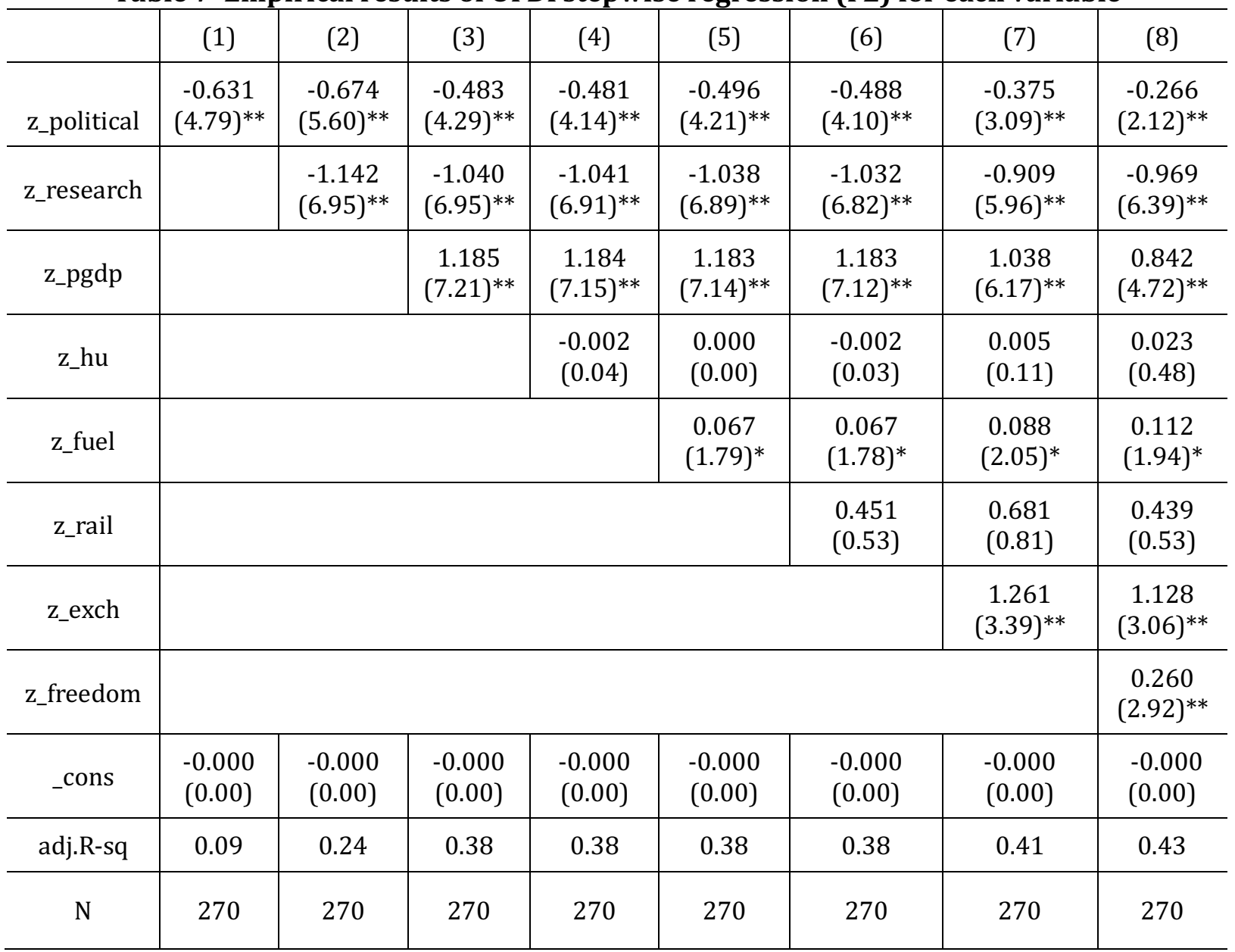

Next, the fixed effect regression results of panel data are analyzed in detail:

(1) Geopolitical risk. From the regression results, we can see that the geopolitical risk score has suppressed the outward FDI under the significant level of 5\%, that is, the higher the geopolitical risk score is, the more unfavorable the attraction of foreign investment will be. The foreign direct investment will take place in the "geopolitical risk" country with "one belt and one road". This result is similar to Buckly $(2007,2008)$. The results are consistent, that is, the host market with political instability can promote OFDI in developing countries such as China. The reason may be that the developed countries with low geopolitical risk will set up barriers to curb China's foreign direct investment, while many developing countries have slightly higher geopolitical risks, but at the same time, because of their rich resources, they attract a large number of foreign enterprises.

(2) Research. It can be seen from the regression results that the overall R \& D expenditure also inhibited OFDI at a significant level of 5\%. The possible explanation is that the time lag effect of R \& D is not conducive to the short-term demand of economic development, so to some extent, it is not conducive to attracting the inflow of foreign capital.

(3) Per capita gross national product (PGDP). The per capita gross national product reflects the overall situation of a country's economic development. From the analysis results, we can see that the impact of per capita GDP on OFDI gradually decreases with the addition of control variables. The possible reason is that the economic development of these countries is not the main reason for China's investment in the "one belt and one road" initiative.

(4) Resource endowment (fuel). This index is significantly higher than zero at the significance level of $10 \%$. It is easy to understand that one of the important reasons for China's foreign direct investment is the abundance of resources and minerals in the host 
country. There are plenty of resource rich target countries in the "one belt and one way" country.

(5) Human resources (HU). From the above analysis results, it can be seen that human resources has not been significantly affected. The possible explanation is that the return on investment of human capital will not be realized in the short term. Theodore W. Schultz once pointed out in the 1960s that in the two kinds of capital, material and human capital, human capital needs to be transformed through investment, which shows the accumulation of knowledge and ability. Another possible explanation is that most of these countries are developing countries or even less developed countries, so the importance of education is far from enough, so the proportion is very small, so it has little impact on OFDI.

(6) Infrastructure. The railways did not significantly affect OFDI in all the regressions. Under the "one belt and one road" initiative, these countries' own infrastructure is not the main reason for China's investment.

(7) exchange rate. From the regression results, we can see that the exchange rate has a positive impact on OFDI at the significance level of 5\%. It means that China tends to invest in countries with high value of RMB, which is consistent with the research results of some scholars, that is, high value of RMB is conducive to foreign investment, which promotes the further growth of OFDI by reducing the cost of overseas assets of Chinese enterprises (Karl P. sauvant \& Ken Davies, 2010).

(8) freedom of system. From the above analysis results, we can see that it has a significant positive impact on foreign direct investment. It is easy to understand that the perfection of a country's system, to a certain extent, reflects the development of its economy and the efficiency of its market.

From the analysis of the model, we can see that the countries with high geopolitical risks in the "one belt and one road" have attracted the investment of our country, which can be explained from the situation of China's foreign direct investment. China's foreign direct investment has certain politicized behavior, and the country with good and stable diplomatic relations with China can invest in its higher geopolitical risk. Case. For a long time, China, as a responsible developing country, adheres to the principle of common development, supports and helps many developing countries and underdeveloped countries in the process of exchanges with foreign countries to minimize the poverty population and reduce the possibility of war, so as to fulfill the commitments made in the Millennium Declaration of the United nations. At the same time, the economic level and exchange rate level have a certain role in promoting OFDI. From the above analysis, we can see that deepening cooperation with the "one belt and one way" country, deeply understanding its geopolitical risk information and enhancing communication can make our foreign direct investment more successful.

\section{References}

Kobrin, S. J ..Political Risk: A Review and Reconsideration [J]. Journal of International Business Studies,1979,(10): 67-80.

Robock.S. H. Political risk: identification and assessment [Jl. Columbia Journal of World Business, 1971,6(4):6-20.

Root, F. R.U. S. business abroad and political risks [J]. The International Executive, 1968,(10): 11-12.

Lensik, Robelt, Hermes, Niels,Murindc,Victor.Capital flight and Political risk,[J]. Journal of.Intemational Money and Finance, 2002,19:73-92.

Haendd. D.Foreign Investments and the Management of political Risks[M]. Boulder, Colorado: Westview,1979.

Ting, W. Multinational Risk Assessment and Management[M], New York: Quorum Books. 1988.

Richard D Robinson. The International Transfer of Technology [J], Ballinger, 1988. 
Rummel,R.J. and Heenan, David, A. How Multinationals Are Andyzing Political Risk .[J]. Harvard Business Review,1978,2:67-76.

Barzel.Y,1989, Economic Analysis of Property Rights, Cambridge: Cambridge University Press.

Hart. 0 and J. Moore, "Property Rights and Nature of the Firm", Journal of Political Economy, 1990, (6):11191158. 